\title{
The difference of oral hygiene status between ethnic group Minang and Sundanese in Pangalengan aged 26-45 years old
}

\author{
Efru Rinaldy*, Sjazili Muhibat*, Anne Agustina Suwargiani* \\ "Department of Dental Public Health Faculty Of Dentistry Universitas Padjadjaran
}

\begin{abstract}
Introduction: Indonesia has a lot of different languages, customs, and food. Each ethnic has a distinctive food of each such Minang ethnic happy with spicy foods and coconut milk, while Sundanese pleased with foods that are sweet and dry. The purpose of this study was to determine the status of oral hygiene ethnic group Minang and Sundanese. Methods: This research use descriptive research. The method used in the study are the type of total sampling method. Samples will be selected according to the criteria of the indigenous people the Minang ethnic and Sundanese ethnic who live in the village Pangalengan district as many as 33 people Minang ethnic and 66 people Sundanese ethnic as a control. Results: Results showed a p-value of oral hygiene status in Minang ethnic communities and Sundanese ethnic communities in Pangalengan is 0.261 . Oral hygiene status in Minang ethnic communities in the district Pangalengan are in the medium category with the numbers 2.7 , while the Sundanese people are in the medium category with the numbers 2.4. Conclusion: The conclusions of this study is there is no difference of oral hygiene status between Minang ethnic and Sundanese ethnic in Pangalengan age of 26-45 years.
\end{abstract}

Keywords: Oral Health Status, Ethnic Minang , Ethnic Sundanese

\section{INTRODUCTION}

The oral cavity is one of most important systems of the human body which has variety function exactly as food and drink entrance into body. ${ }^{1}$ There are several different organs in oral cavity such as tooth and its supporting tissues (periodontal), muscles, tongue, jaw bone, etc. ${ }^{2}$

The tooth is a unity with the other members of the body, so that when there is disturbance or diseases of the teeth will result in reduced quality of life. ${ }^{2}$ Thus, it is important to maintain of the oral healthto maintain the quality of life because according to the Health Department of Indonesia 2009 , the oral cavity is often attacked by various diseases. The disease most often affects the oral cavity are dental caries and periodontal disease. ${ }^{3}$ Dental caries attack the hard tooth structure that is caused by the metabolic activity of the bacteria that is present in biofilm. ${ }^{4}$

Bacterium will ferment carbohydrates to produce acid and cause a $\mathrm{pH}$ imbalance around the teeth. ${ }^{5}$ When the $\mathrm{pH}$ reaches the critical point $(\mathrm{pH}=5.5)$, it will cause the demineralization of tooth structure. Furthermore, the $\mathrm{pH}$ around the teeth will return to normal if there is a process buffer by saliva or remineralization process. ${ }^{5}$ If the demineralization process is more dominant than the remineralization process, it will cause proteolysis of the organic components of tooth 
tissue. $^{5}$ Dental caries is a chronic disease that has been exist from earlier. In addition, dental caries is an oral health problems are most often found in the world. ${ }^{3}$ Influenced by four important factors, such as environmental, behavioral, health service, and heredity factors. ${ }^{7}$ Environmental factors, exactly social and cultural aspects, is an important factor determining the health status, exactly oral health, of people.

Culture in the form of customs, habits, and beliefs will affect a person's behavior to health care. ${ }^{8} 47$ Indonesia has a wide variety of ethnic groups, some of which is Minangnese and Sundanese. Every ethnic group in Indonesia has different culture and habits in the consumption of each food type. Minangnese is not used to eating vegetables or fresh vegetables compared to the Sundanese.

Minangnese eating culture tends to be more often eat food containing coconut milk, fat, and spicy, while Sundanese few contain coconut milk and fat. ${ }^{9}$ also adds that Minangnese have a tendency to eat foods that contain lots of protein and milk compared to the Sundanese are more varied in eating food, such as food containing animal protein, vegetable protein, vegetables, and fruits. Variations in diet can have an impact on the level of oral health. ${ }^{10}$

Revealed that every ethnic culture or community can affect the level of its public health. ${ }^{11}$ Culture is owned by a community will produce a mindset taste, ideas, knowledge, and attitude towards the health. ${ }^{12}$ Each ethnic group has its culture each others. One of the results of culture is a dietary habit so that the culture and dietary habit has a very close relationship. ${ }^{12}$ Thus, the oral health status of each ethnic group vary according to the food they consume each day often. Age can also affect oral health conditions. ${ }^{13,14}$

The Department of Health (2009) classified age into several categories; toddler, childhood, adolescence, adulthood, and eldery. Adulthood is divided into two phases: the early adults (2635 years old) and the end of adults (36-45 years old). Research conducted by Unilever (2013) showed that $79 \%$ of adults have less attention to health and oral hygiene such as not brushing their teeth twice a day and check their oral health to the dentist rarely. This condition is more susceptible to dental and oral diseases such as caries, periodontal disease. ${ }^{15}$ Based on the above information, Minangnese communities who consume more foods containing coconut milk and less vegetables will have a $\mathrm{OHI}$ smaller than the Sundanese who consume foods containing coconut milk and often eat vegetables.

Based on that information, the authors are interested to conduct the research on $\mathrm{OHI}$ difference between Minangnese and Sundanese ethnic group in adulthood age group (26-45 years old). This study has a purpose to determine the $\mathrm{OHI}$ difference between Minangnese and Sundanese ethnic group aged $26-45$ years so it can be used as a evaluation source and planning model of oral health service system in improving the oral health status in Indonesia.

\section{METHODS}

The research strategy was deductive and the type was descriptive comparative. The population used in this study are native Minangnese and Sundanese ethnic group who reside in Sub-district Pangalengan, Bandung, West Java. Minangnese total population aged $26-45$ years as many as 33 people and as many as 1,186 people of Sundanese. Samples were taken with total sampling with the sample size Minang Ethnic 33 people with 66 people Sundanese ethnic group, as comparasion, aged 26-45 years.

Research Variable There were three variables of this research, namely dependent variable, independent variables, and confounding variables. The dependent variable is Oral Hygine Index, and the independent variables were Minangnese and Sundanese ethnic group. Also there were confounding variables, such as health services, behavior, and environment. Research Procedure The first one, the researchers prepared the tools and materials research, second then the research subjects filled out and signed an informed consent.

Informed consent is a consent of the research subject or representative that previously have received an explanation from the researchers. After obtained a consent, researchers and their assistants prepared to do this research. Preparations conducted by researchers is to wear a mask, wash hands, then put handscoon. When 
the operator prepared the research, staff was recording data or identity of research subjects. Then, the operator instructed the subject of research for gargling first. Afterwards, the operator checked oral hygine index and the assistant noted the results on the examination form that has been prepared before. Finally, researchers gave the research subject oral health education. Data obtained from research were collected and then were processed to get an overview and conclusion.

Processing results were presented in tabular form and analyzed with nonparametric statistical test (Chi Square Test). Chi squared test was a statistical test used to compare differences in the frequency of results of observation $(0)$ with the expected frequency $(E)$.

The following principles of the test were:the data were analyzed in the form of data categorical, calculate the difference value between the research results and the expected results, there was no expected number having a value $<1$, amount of the cells with the expected number ofare not over $20 \%$ of the total cells.If this happens on a $2 \times 2$ contingency table then do Fixer exact or Yates Correction (Kirkwood, 2007).

\section{RESULTS}

This research was conducted to determine the DMF-T index difference between Minangnese and Sundanese ethnic group aged $26-45$ years. To obtain data of Minangnese Oral Hygiene Index, the author conducted research in the Qur'an recittion community of Minangnese and in stores or markets where they work. To obtain data on Oral Hygiene Index Sundanese, the authors do this research in health centers (Puskesmas) and in their houses.

The subject of research from Minangnese group aged 26-45 years and live in Pangalengan originally planned totaling 33 people to 32 people. This was caused by a person subject refused to participate in the study. The subject did not want to participate in this study because subjects feel the teeth and mouth clean so it was not necessary examinations despite having been given an explanation by the researchers.

Thus, the total research subjects in the group of Sundanese as a control sample that originally numbered 66 to 64 people. Total research subjects in this research amounted to 96 people. Subjects
Based on the research that has been conducted, the authors obtain data about the characteristics of the research subjects by gender and the age group described on Table 1.

Table 1 explains that the number of research subjects Minangnese in this research amounted to 32 people. The research subject Minangnese is dominated by male that amounted seventeen people while female subjects fifteen people. The research subject of Sundanese totaling 64 people dominated by women, as many as 42 people, while the male subject as many as 22 people.

Table 1. Research Subject Characteristics by Sex

\begin{tabular}{ccc}
\hline Sex & \multicolumn{2}{c}{ Ethnic Group } \\
\hline Minangnese & Sundanese \\
\hline Men & 17 & 22 \\
Total & 15 & 42 \\
\hline
\end{tabular}

Table 2. explains the characteristics of subjects stratified by age group. The data presented in the above table shows that most respondents Minangnese as many as 18 people aged $36-45$ years and as many as 14 people aged $26-35$ years. Unlike the Sundanese, the majority of respondents as many as 35 people aged 26- 35 years and as many as 29 people aged $36-45$ years.

Table 2. Measurment Sciences about Anatomy Teeth socket

\begin{tabular}{ccc}
\hline Age Group & \multicolumn{2}{c}{ Ethnic Group } \\
\hline & Minangnese & Sundanese \\
\hline $26-35$ years & 14 & 35 \\
$36-45$ years & 18 & 29 \\
\hline Total & 32 & 64 \\
\hline
\end{tabular}

This research aims to determine the Oral Hygiene index difference between the Minang tribe Sundanese Age 26- 45 Years. The components as the statistical test results can be seen in the Table.

\section{DISCUSSION}

The results of this study indicate that the oral hygiene status of Minangnese people in Pangalengan subdistrict aged $26-45$ years is in the criteria medium. The condition is supported by research conducted by Alhamda shows that the number of oral hygiene status of Minangnese 


\begin{tabular}{|c|c|c|c|c|c|c|}
\hline \multirow{2}{*}{ Oral Hygiene Index } & \multicolumn{3}{|c|}{ OHI-S } & \multirow[t]{2}{*}{ Total } & \multirow{2}{*}{$\frac{\text { value of }}{\mathrm{p}}$} & \multirow{2}{*}{ Information } \\
\hline & Good & Medium & Bad & & & \\
\hline Minangnese & 2 & 19 & 11 & 32 & & \multirow{2}{*}{ there is no difference } \\
\hline Sundanese & 8 & 43 & 13 & 64 & & \\
\hline Total & 10 & 62 & 24 & 96 & 0.261 & \\
\hline
\end{tabular}

people in Bukittinggi city is also in medium category. ${ }^{16}$

This occurs due to the effects of food consumed by the Minang tribe community that contains a lot of coconut milk. ${ }^{13}$ Consuming coconut milk excessively accelerates the process of hydrolyzing the fatty ester into free fatty acids which then becomes calcium phosphate.

Calcium phosphate is one of the components of calculus composition, so the fat from coconut milk can improve the process of plaque formation and calculus. ${ }^{17}$

Result of research of oral hygiene status at Sundanese tribe in sub district of Pangalengan age 26-45 years same with Minang tribe that enter in medium category.

This is due to the mixing of Minang and Sundanese tribes in Pangalengan sub-district where Minangese have adapted to the environment and the Sundanese community. ${ }^{18}$

Besides the information obtained from the respondents, quite a lot of typical Minang restaurants in the district of Pangalengan cause the people of the tribe of Sunda is no longer pegged to the typical food.

This resulted in awareness of both Minangnese and Sundanese communities towards their health and oral hygiene similar to those of their same neighborhood. ${ }^{7}$

The information obtained from the respondents when the data collection is done that Minangnese tribe people who live in Pangalengan sub-districts have been on average for more than 5 years. Adaptation is done by someone to fulfill one of basic human need, that is survival requiremen. ${ }^{18}$

This resulted in no significant difference in oral hygiene status between Minangnese and Sundanese tribes in Pangalengan sub-district aged 26-45 years.

\section{CONCLUSION}

Conclusions of this study there is no significant difference between the oral hygiene status of Minangnese and Sundanese tribes in Pangalengan sub-district aged $26-45$ years.

\section{REFERENCES}

1. Chrismawaty BE. Peran Struktur Mukosa Rongga Mulut dalam Mekanisme. Blokade Fisik Terhadap iritan. MIKGI. 2003;9:244-50.

2. Moore WEC. Microbiology of periodontal disease. J Periodontol Res. 2006 Sep;41 (5):33541.

3. Darwita RR, Novrinda H, Budiharto, Pratiwi PD, Amalia R, Asri SR. Efektivitas Progam Sikat Gigi Bersama Terhadap Risiko Karies Gigi pada Murid Sekolah Dasar. J Indonesian Med Assoc. 2011;61:204-9.

4. National Institute of Health Research and Development (NIHRD). Indonesia Basic Health Research (RISKESDAS) 2008-2009. Jakarta: Ministry of Health Republic of Indonesia; 2009.

5. Robertson PB, DeRouen TA. Controversies in periodontology. Periodontol 2000. 2002;30(1):7-8.

6. Fejerskov O, Kidd E. Dental Caries: The Disease and Its Clinical Management. 1st ed. Copenhagen: Blackwell Munksgaard; 2003.

7. Banerjee A, Watson TF, Paolinelis G, Socker $M, M c D o n a l d ~ F$. An in vitro investigation of the effectiveness of bioactive glass air-abrasion in the 'selective' removal of orthodontic resin adhesive. Eur J Oral Sci. 2014 Oct;122(5):48892.

8. Mount GJ, Hume WR. Preservation and Restoration of Tooth Structure. 2nd ed. Queensland: Knowledge Books and Software; 2005. 
9. Notoatmodjo S. Metodologi penelitian kesehatan. Jakarta: Rineka Cipta; 2003. p. 146-7.

10. AzwarA. Pengantar ilmu kesehatan lingkungan. 3rd ed. Jakarta: Mutiara; 1983.

11. Anwar F, Khomsan A. Sehat Itu Mudah. Jakarta: Hikmah; 2008.

12. Efendi F, Makhfudli. Keperawatan kesehatan komunitas: Teori dan praktik dalam keperawatan.

13. Raharja S. The relationship between cariogenic food eating dailly pattren and the occurence dental caries children on pre school children (Case study in pre elementry school Aba Bodeh Gamping Sleman) [minor thesis]. Semarang: Undip; 2005.

14. Lanonchi SJ. Hubungan pelayanan kesehatan dengan kepuasan pasien rawat inap pengguna Jamkesmas di ruangan Seroja Rumah Sakit Undata Palu [university repository]. Palu: Universitas Muhammadiyah Palu; 2012.
15. McElroy A, Townsend PK. Medical Anthropology in Ecological Perspective. 4th ed. New York: Avalon Publishing; 2002.

16. Manurung AKW. The impact of xerostomia to oral health related quality of life in elderly [minor thesis]. Semarang: Undip; 2012.

17. Wowor VE, Rattu AJM, Wicaksono D. Hubungan antara Status Kebersihan Mulut dengan Karies Siswa Sekolah Menengah Atas Negeri 1 Manado. J e-GiGi. 2013;1(2):1-10.

18. Alhamda S. Dental and Oral Hygiene Status with Dental Caries Status (Study in Student Age Group 12 Years in Elementary School City of Bukittinggi). Berita Kedokteran Masyarakat. 2011 Jun;27(2):108-15.

19. Academia [homepage on internet]. Yosa RW. 2013. Plak dan Karang Gigi. [cited 2012 Jun]. Available from : http://www.academia. edu/8646944/130292576-Plak-Karang-Gigi

20. Suparlan P. Hubungan Antar Suku Bangsa. Jakarta: Rineka Cipta; 2004. 